\title{
3D Body Scanning with Mobile Application: An Introduction to Globalise Mass-Customisation with Pakistani Fashion E-Commerce Unstitched Apparel Industry
}

\author{
Sadia IDREES ${ }^{1}$, Gianpaolo VIGNALI, Simeon GILL \\ The University of Manchester, Manchester, UK
}

\begin{abstract}
The study aims to explore the 3D Body scanning mobile application Nettelo to determine mechanism, precision and level of acceptance of application for mass-customisation of garments. The mix-methods (Quantitative and Qualitative both) approach has been conducted to determine the responses of Pakistani consumers. Participants' responses have been analysed with try-on bespoke garments constructed by digital measurements extracted from 3D body scanning mobile application. Bespoke garments are well established and commonly utilised by consumers of Pakistan [1]-[3]. Additionally, Pakistani fashion brands are famous for selling and designing unstitched apparel products which are economical and sustainable, to be used as a personalised tailored garment [1]-[3]. However, traditional body measurement technique has been used to construct garments, which is a major obstacle to establish globalise mass-customised garments business using e-commerce fashion platforms. To extract digital human measurements for garments customisation, high and low-tech 3D body scanning mobile applications are available to both IOS and Android users [4]. In addition, these web 3.0 technologies virtual size and fit tools and 3D body scanning technology have the potential to enhance the fashion e-commerce environment for online bespoke apparel shopping. The reliability of 3D body scanning technologies has been evidenced in various studies [5]-[8]. The unstitched apparel product is famous in South-Asian countries, especially Pakistan has one of the biggest unstitched apparel industries with diversity in style, designs, and price range [9]. The growth of 3D body scanning technology and virtual size and fit to enhance the consumer satisfaction level with sustainability in terms of bespoke garment construction is the most promising e-commerce fashion business model under development presently [10], [11]. 3D body scanning mobile applications have the potential to initiate globalise mass-customisation in fashion e-commerce Industry.
\end{abstract}

Keywords: 3D body scanning, mobile application body scanning, e-commerce, mass-customisation

\section{Introduction}

Apparel products cannot be constructed to impeccably fit everyone using standard body measurements. The key factor of purchase intent is garment fit [12], [13]. Each individual has different body type and weight which have a significant impact on how a garment would fit each individual choosing among ready to wear [14]. The unstitched apparel product has a potential to amalgamate with 3D body scanning technology for customisation of garment according to consumer body measurements. In actual fact, Pakistani women are incredibly particular about fashion and prefer to wear tailored garments as per their own designs to maintain their personalise look, is a common practice across the country [3]. Additionally, unstitched product is bought by masses because tailored clothes are economical for consumers in Pakistan. Many women work as home-based tailors, which further aid the profession as well as the economy of the fashion world in Pakistan [15]. There is continuous evolution in the shape of population. To enhance apparel production, 3D body scanning is needed to frequently appraise fashion industry sizing systems and ensure that constructed garments perfectly fit the shape of the population [16], [17]. The 3D Body scanning systems were updated in the last 15 years with parallel cost reduction and have entered in consumer market especially, structured light scanners with easy to transport, high resolution, fast and at affordable price. Since their introduction scanners were explored with the perspective of made to measure garments, mass customisation because of its function to extract rapid body dimensions that are necessary for garment construction. It is observed that scanners also offer an opportunity to increase online sales by selecting the best fitting size from range of pre-manufactured sizes [18]-[23]. Recent technologies introduced to apparel e-commerce for

\footnotetext{
${ }^{1}$ Note: Sadia Idrees (Ph.D. researcher) is with the Department of Materials, Faculty of Science and Engineering, Sackville Street Building M13WE, University of Manchester, UK (phone:0161 306 8846; e-mail: sadia.idrees@manchester.ac.uk)
} 
custom-made products, which includes 3D body scanning, size recommendations, fitting predictions and virtual try-on simulations [24]. Such technologies are a compound of complex systems for the digital transfiguration of merchandising, manufacturing and supply chain industries. Presently, there is a comprehensive range and choice of 3D body scanning technology. Each scanner has its strengths utilising a variety of acquisition technologies[18], [25]. These scanners are available at prices ranging from tens to hundreds of thousands of dollars (e.g. 3DMDbody, Botspot, Ditus, Fit3D, IIIDbody, Intellifit, Shapify Booth, SizeStream, Styku, Symcad, Texel, [TC]2, Vitus, etc.). In recent years, high- and lowtech mobile applications have been introduced to the market, which are easily accessible to consumers and retailers. These applications are available at affordable prices and some of them are free to use. For instance, Mirrorsize, 3D size Me, 3D Greater, Bevel, Canvas, Itseez 3D, Qlone, Scandy Pro, Scann 3D, IBV, 3D Look, 1 Measure, Fit measure, Nettelo and Size stream at Home (Me Three Sixty). Such technologies are introduced to provide digital body measurements for personalised fitness tracking. Moreover, these technologies have a prospective to enhance online fashion apparel store experience. $3 \mathrm{D}$ body scanning applications has a potential to introduce globalise made-to-measure apparel ecommerce market.

Fashion brands of Pakistan are extensively using web 2.0 technologies in their fashion e-commerce platforms to fashion viewing and providing services to consumers. To advance the e-commerce industry there is a requirement of constructive development for wider collaboration with consumers. 3D body scanning technology is embedded with artificial intelligence and semantics and can conclude the user demand and choice through deductive reasoning. Traditional manual measurement method for constructing bespoke garments is a hurdle in establishing e-commerce platforms for bespoke garment construction. This can be enhanced by digitalisation and addition of 3D body scanning technology for fashion e-commerce platforms which eventually introduce automated tailoring by using these digital measurement applications. Thus, the facilities of constructing mass-customised garments in the international market with the right size and the fitted garment can be enhanced with breakthrough web 3.0 technologies [26]. The aim of the study is to explore the mechanism, precision and level of acceptance of consumers by collecting consumer responses with trying-on bespoke garments with extracted digital measurements using 3D Body scanning mobile application technology. Thus, to develop Pakistani fashion e-Commerce platforms enhanced by 3D Body Scanning Technology. Consequently, this study addresses three research objectives:

1.To understand the mechanism (ease of use) of 3D Body scanning applications, because there is a requirement to evaluate the potential of 3D Body Scanning to connect with unstitched garment product of Pakistan for mass customisation.

2. To comprehend the precision of $3 \mathrm{D}$ body scanning application with try-on process because there is a need to facilitate the consumers with innovative application of extracting anthropometric data to provide global services of bespoke garments in Pakistan fashion e-Commerce.

3. To evaluate level of acceptance (innovativeness, usefulness, attitude, intended use, post use evaluation), of 3D body scanning technology by consumers how much they are satisfied with the offered technology for constructing bespoke garments in terms of size and fit.

To address the research aims, this paper explores the consumer online bespoke shopping journey by extracting digital measurements by themselves using mobile application. Those measurements were sent to a tailor for garment construction (Traditional dress worn by Pakistani consumers). After trying on bespoke garments, the responses were evaluated through Mix-method approach. Quantitative data analysis is concluded by using TAM constructs (Technology Anxiety and Innovativeness, Perceived ease of use, Perceived usefulness, perceived entertainment value, attitude, intended use). For post use evaluation (qualitative) of garment open ended questionnaire have been constructed.

\section{Literature Review}

Charoensiriwath and Tansprasert in 2010 conducted a case study in Thailand, where 3D body scanners were practiced in the apparel and healthcare industries. A Made-To-Measure Clothing project conducted, aimed to come up with new MTM process that is more suitable to be used by Thai tailors. Bespoke suits and uniform trial were carried out with tailors, manufacturers and fashion students. Study determined successful results by analysing high percentage of well fitted suits in which little or no alterations were required after trying-on. [27]. Styku (MyBodee) 3D body scanner has been studied to explore the potential for Bespoke garments constructed with using 3D technology. Men's jacket was constructed by employing 3D body scanning and 3D virtual simulation technology. It is recommended by study that the jacket constructed from the mass customisation process was acceptable to potential 
male consumers and was evaluated as much better approach than ready-to-wear jacket. 3D body scanning technology is revealed to be an innovative tool for future tailors and men's wear industry, especially targeted at young male consumers. Study revealed the potential for the use this technology for menswear apparel construction [28]. Precision of 3D Body scanning technology have been studied by Romeo in 2017 [29] by using four different infrared depth sensor machines: Fit3D Proscanner; Styku; TC2 KX-16; and Size Stream. Photographs and notes of machines were taken during participant ease of use and comfort during the scan. Results established diversity in machine hardware impinge in both data collection accuracy of scanner, participant ease of use and comfort during scanning process. Each 3D Body scanner has its own proprietary software for land marking and measuring. Thus, vital measurements required for apparel production, for instance, waist measurements fluctuate in the location on the participant's body where data has been collected, consequently the absolute values vary for the named location. Variation has been observed in the number and type of measurement extracted by each scanner's proprietary software, and the skill of investigators to regulate points of body measurements on the avatar. Organization and presentation of data of measurements by the proprietary software, and the accessibility of the OBJ file, of two scanners were determine to be more allied to the requirements of the apparel industry [29]. Therefore, land marking and measuring accuracy is vital for scanner brands to be comparable for incorporation into fashion industry by establishing and using similar and reliable land marking and measuring standards to deliver more accurate results to retailers and consumers.

\subsection{Body Scanning Limitations and Errors}

The body scanning systems has dissimilar acquisition technologies in context with the mechanism and measurement techniques of body scanner and errors that have experienced during body scanning process. To address these errors researchers have presented reliability measures [30], [31], complications in capturing body dimensions and landmark identification [32]. To permit the 3D body scanner to be incorporated into fashion enterprise supply chains with an achievable sustainable solution, these contradictions must be addressed. Digital measurement extraction is problematic identified by Apeagyei (2010) [16] and Han and Nam (2011) [32] in their study. Body landmarks are recognised through the parting of the body at key points on parameters which can be challenging. Such as, "the crotch is determined by where the two legs meet the torso. In cases where the meeting point of the thighs is can be mistakenly identified as the crotch, missing data results. The presence of hair at the back of the neck prevents the identification of the 7th cervical vertebra at the back of the head, which is needed to calculate heights in the body that determine other measurement locations (e.g. armpits).The armpits and crotch region landmarks can be distorted by improper limb placement (e.g. non-muscular arms), shading or reflection on the body or small underwear that does not define the difference between the legs and torso regions" [33] p.183. These inconsistencies are addressed by Ashdown and $\mathrm{Na}$ (2008) [34] and Gill et al. (2014) [35] determined the accurate location of some landmarks for garment construction. To ensure accuracy of these landmarks to confirm precision a widespread scan cleaning method should be employed. However, there are differences in pattern construction method and measurement locations used by various retailers that subsist within garment producers throughout fashion supply chains [36]. Gill et al. (2017) [37] indicated that not all body scanning measurements are valid for manual garment development procedure. Variation in design and product development practice in fashion industry is consequently required for all 3D body scanners to be implement in fashion apparel supply chain [33]. 3D body scanning mobile applications will be studied keeping in consideration landmarks identification and limitations of each body scanner under research.

\subsection{ISO standard 8559-1:}

The standard used by most 3D body scanning applications is ISO 8559-1. This standard is used for landmark identification to extract digital measurements of an individual [38].

\subsection{Unstitched Apparel Product}

Pakistan has a diverse online and Brick and Mortar market of Unstitched apparel product which is bought by masses. This product is common in South Asian countries and specifically designed to construct made to measure garments [9]. The term Unstitched can be defined as a pre-stitched product which is available in the market with various options of printed and embroidered fabric with specific length and width in meters and yards. Unstitched product has options of 3 piece (Trousar/Shalwar, Shirt and Dopatta) and 2 piece garments (Trousar/Shalwar, Shirt and Dopatta) and 2 piece garments (Trousar/shalwar, Shirt) or (Shirt, Dopatta) [39]. Interestingly, Pakistan has a rich history when it comes to textile designing and tailoring of clothes [40]. The concept of tailoring clothes for individuals specifically has existed in Pakistan since long and the costs associated with tailored clothes are 
generally inexpensive in Pakistan [1]. In contrast, the UK population is more accustomed on choosing clothes that are pre-stitched or ready-made. The idea of buying a fabric, choosing a design and getting it stitched in the size that fits best to an individual is a common custom in Pakistan [2]. This makes it important to identify how the concept of body measurements work in Pakistan and whether the 3D body scanning methods could become common in Pakistan [41].

\subsubsection{Unstitched Apparel: A Sustainable Product}

A single design is replicated for diverse population, which heightened the wastage of fabric. The standard size measurement methods were used for garment production which lead to unsatisfied consumers in terms of size and fit. This approach cuts down the window of sustainability [42]. However, unstitched apparel product can be personalised according to specific consumers and cloth wastage can be reduced. Therefore, this approach can lead to sustainable apparel construction environment [43]; [44].

\section{Theoretical Background}

The theory of diffusion of innovation explicates the method by which an invention is presented, elucidation, estimated and, subsequently, either approved or disapproved. Initially consumers try latest technology on a partial basis, on observation of advantage in using it they espouse the innovation [45]. Within the literature implementation, insights of features of invention such as comparative advantage (usefulness and entertainment value) and intricacy (ease of use) [45], [46] and also distinction in specific buyers [47]-[50] have been revealed to envisage implementation of behaviours. Hoffman and Novak (1996) [51] originate that anxiety related to the aptitude to accomplish a demeanour was negatively associated to actual demeanour usage. Studies reveal that consumers with greater levels of technology anxiety practise limited self-service technologies, and that professed negatively to the latest technologies [48]. TAM theoretical model supports as a tool, to investigate and predict user acceptance of latest technology e.g., [52]-[55]. Founded on the Theory of reasoned action (TRA), TAM emphases on the aspect of ease of use and usefulness in envisaging approach toward using a new technology [53]. The hedonism construct has been added to TAM to elucidate the aspect of intrinsic enthusiasm in the acceptance of a novel technology [56], [57]. Heijden (2000) [58] modified the genuine TAM for a website environment, recommending the e-TAM framework, and establish the discernments of perceived relative usefulness and perceived relative enjoyment were strong effective aspect to adopt. However, for website revisit intention perceived usefulness and perceived enjoyment are strong aspects, website revisit intentions are indirectly affected by perceived ease of use by persuading the perceived relative usefulness and perceived relative enjoyment [58]. The e-TAM model is persistent with former research on retail shopping behaviour and abutment the existence of both utilitarian and hedonic drives for online shopping [59], [60]. Functionality of a technology reflects perceived usefulness, and hedonic aspects of technology reflects enjoyment for online shopping process within e-TAM theoretical model.

Though some users may utilise (3D Body scanning) technology chiefly for practical purposes, such as enhanced multifaceted inspection of a technology, some may utilise it chiefly for hedonic resolutions [60], by extracting digital measurements and viewing virtual model and tracking measurements from the previous measurements after workout. As online buyers would discover 3D Body scanning technology to be operative in plummeting product risk in terms of size and fit, escalating shopping enjoyment, or both, consumers will be more likely to accept it.

\section{Methodology}

A Mix-method exploratory study has been conducted using 3D Body scanning mobile application to determine the responses of Pakistani consumers. The sample was recruited using (non-probability) convenience sampling method [61]. The 5 participants scanned themselves at home (wearing close fitting dress, no accessories with hair tied-up in a bun form) with Nettelo 3D body scanning mobile application to extract digital anthropometric measurements. Researcher provide information about mechanism of using mobile application via zoom conference. After scanning themselves with application the participants sent body measurements to researcher by e-mail. The digital measurements were sent to Tailor via WhatsApp messaging and calling application and Unstitched fabric shirt (2.5 metre) and Trouser (2.5 metre) 2-piece unstitched product, five unstitched garments were purchased from local Pakistani market in Lahore and sent to tailor for personalised tailoring. It took him around 3 days to sew the garments according to given measurements. The tailored garments were then sent to participants to try-on and online survey questionnaire link (Select Survey by University of Manchester) 
has been provided after they have try-on their personalise garments. Online survey results have been analysed in terms of size and fit of a garment and to understand the validity and reliability of 3D body scanning application. The technology acceptance model constructs have been adopted to develop online survey questionnaire. A structured questionnaire based on TAM constructs and size and fit assessment of a bespoke garment for generalisation and external validity of results. The NETTELO application has been considered in the study because it is free for users. Quantitative data analysis has been conducted with SPSS software.

\subsection{Online survey}

An online survey with mix-method approach was developed to examine the acceptance of 3D body scanning with mobile application by Pakistani female for online bespoke apparel shopping aged 18-65+ [62]. Quantitative: The constructs were measured using 7-point Likert-type scales ranging from 1 (strongly agree) to 7 (strongly disagree) and 7-point semantic differential scale. A total of 24 items (quantitative analysis) were used to measure the seven latent constructs: technology anxiety (TA), innovativeness (INN), perceived usefulness (PU), perceived ease of use (PEOU), perceived entertainment value (PE), attitude (ATT), intended use (USE). Qualitative: For post-use evaluation (EVA) (performance evaluation, aesthetic evaluation and 3D body scanning application evaluation) of bespoke garment open ended questionnaire have been developed for qualitative analysis of the study. A total of 12 items were used to measure the post use evaluation of size and fit of a garment. Conceptual definitions and sources are presented in Table 1.

Table 1. Conceptual Definitions and Sources of Constructs

\begin{tabular}{|c|c|c|}
\hline Construct & Conceptual Definition & Source \\
\hline Technology anxiety & $\begin{array}{l}\text { The feeling of fear and apprehension by a user } \\
\text { when thinking and actually utilising a } \\
\text { technology (3D Body scanning) linked tools. }\end{array}$ & [63], [65] \\
\hline Innovativeness & $\begin{array}{l}\text { The readiness of an individual to try a novel } \\
\text { (3D Body scanning) technology is named as } \\
\text { innovativeness. }\end{array}$ & [49] \\
\hline Perceived usefulness & $\begin{array}{l}\text { The level of person's perception that using a } \\
\text { (3D Body scanning) technology would } \\
\text { improve his or her task-related act. }\end{array}$ & [53] \\
\hline Perceived ease of use & $\begin{array}{l}\text { The level of person's perception that using a } \\
\text { technology would be effortless. }\end{array}$ & [53] \\
\hline $\begin{array}{l}\text { Perceived } \\
\text { entertainment value } \\
\text { (perceived enjoyment) }\end{array}$ & $\begin{array}{l}\text { The level of enjoyment perceived by a user } \\
\text { while using a ( } 3 D \text { Body scanning) technology, } \\
\text { aside from any performance consequences } \\
\text { that may be foreseen. }\end{array}$ & [56] \\
\hline Attitude & $\begin{array}{l}\text { A complete affective assessment (of using 3D } \\
\text { Body scanning) that can fluctuate from } \\
\text { extremely positive to extremely negative. }\end{array}$ & [60] \\
\hline Intended use & $\begin{array}{l}\text { Buyers' intention to use (3D Body scanning) } \\
\text { technology in future during online shopping. }\end{array}$ & \\
\hline Post-use evaluation & $\begin{array}{l}\text { A subjective evaluation of a buyer of any } \\
\text { outcome and or an experience linked with } \\
\text { using (3D Body scanning) technology. }\end{array}$ & [66] \\
\hline
\end{tabular}

\section{Results and Analysis}

The findings section explains the mechanism of Nettelo application as well as consumers responses towards 3D body scanning mobile application use for bespoke garment construction.

\subsection{Mechanism of Application}

Mechanism of NETELLO 3D body scanning mobile application has been explained below with images for holistic understanding. Nettelo application can be installed free from Apple store. 


\subsubsection{Feature 1}

Scanning of Body from front and side view.

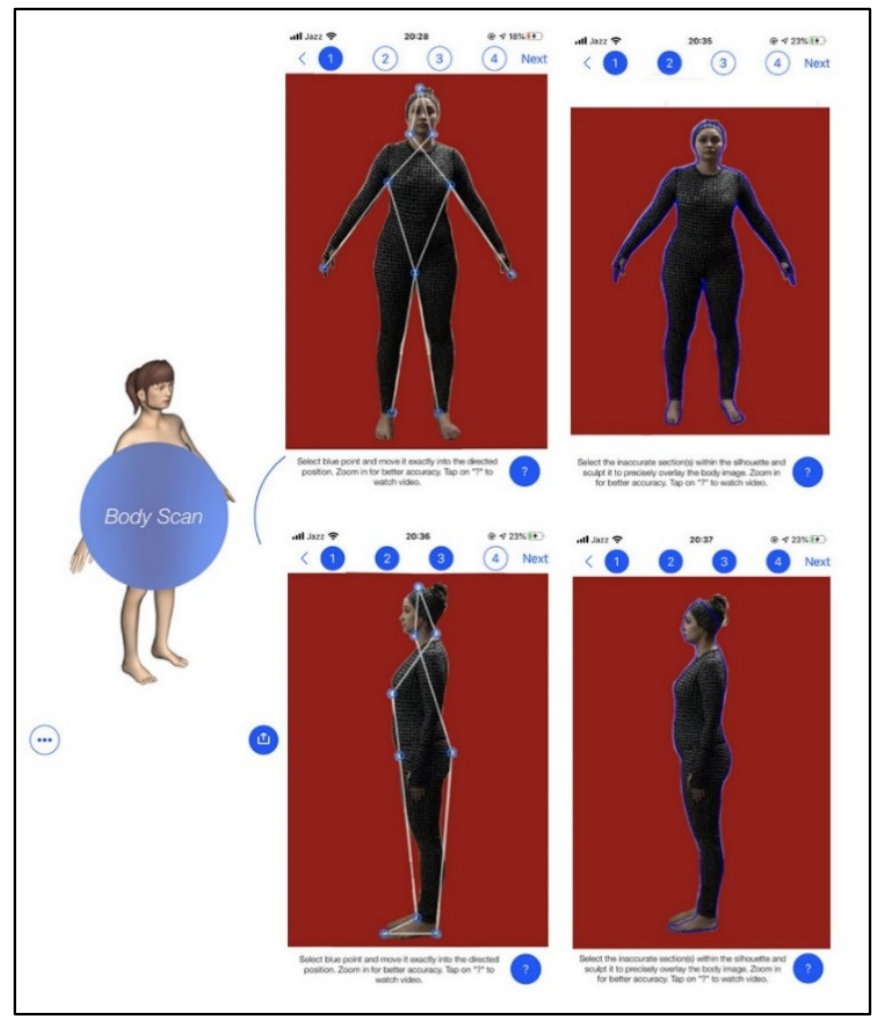

Fig. 1. 3D Body Scanning Process with Nettelo

After scanning, Body specific parts has been marked, such as, head top, sides of face near chin, under arm points, crotch point, hands end points and toe points. Then, Body silhouette has been created to give an outline to an image. Similarly, for side view image body points has been marked such as, head top, under chin near to neck, back neck joining shoulder, under breast landmark, hip highest point, crotch point, foot heel, toe and front centre of foot joining leg. Then, side view silhouette has been created by tapping lines and adjusting according to body curves. After full satisfaction with created body outline the image has been submitted to be process by application for extracting body measurements. The application asks for participant height and weight, before extraction of body measurements. Finally, participant can view personalise avatar and body measurements. The features offered by Nettelo has been discussed below with images captured from mobile.

\subsubsection{Feature 2}

To view personalise Avatar

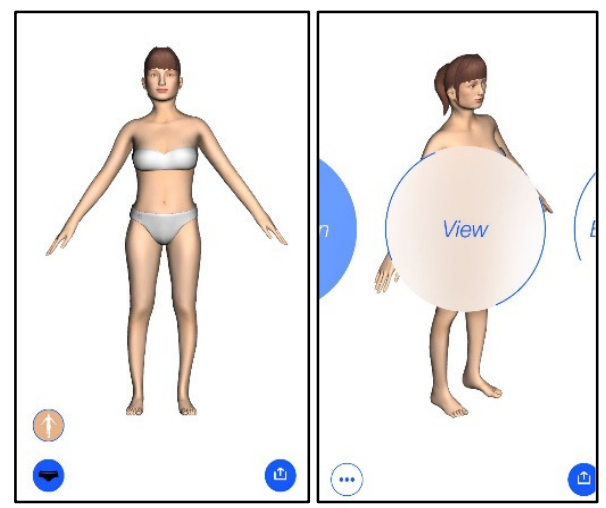

Fig. 2. Personalise Avatar 360 Degree View 


\subsubsection{Feature 3}

Body measurements data is uploaded in the body metrics feature.

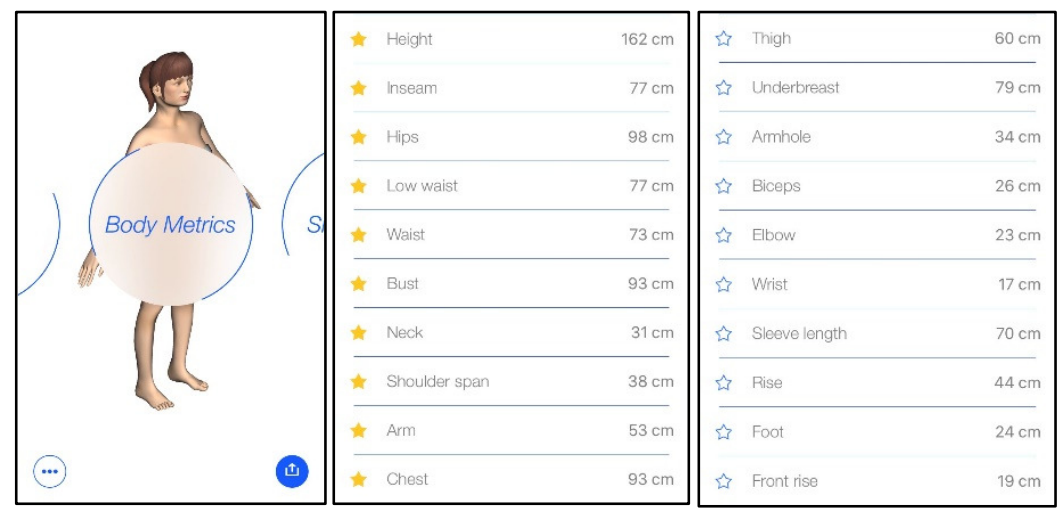

Fig. 3. Body Metrics Data

\subsubsection{Feature 4}

Size advice is recommended in the size advice option in the application.

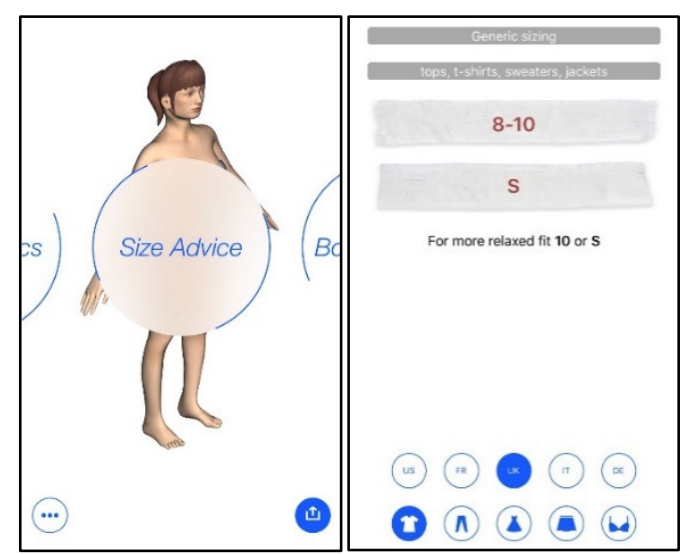

Fig. 4. Size Recommendation for Ready to Wear

\subsubsection{Feature 5}

Body measurements tracking option can be used to compare body measurements after workout.

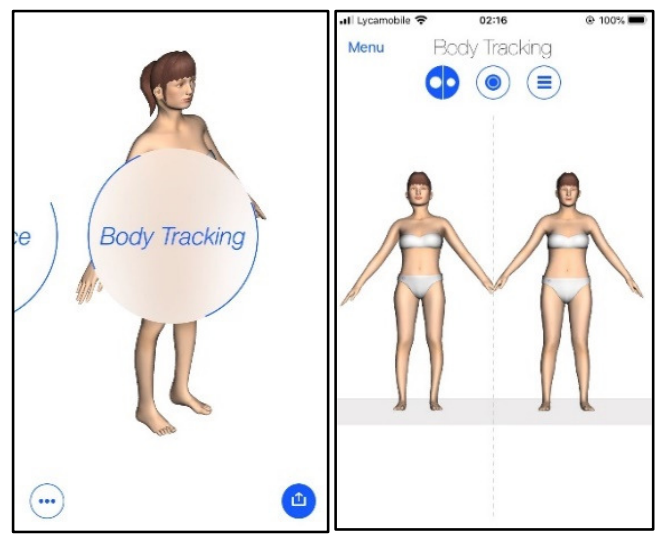

Fig. 5. Comparative Analysis of Body Measurements

\subsection{Quantitative Analysis}

5.2.1 Analysis of respondents after trying-on Bespoke garments constructed with digital body measurements by 3D Body scanning application (Nettelo)

The purpose of the study is to facilitate consumers with novel technology of extracting digital measurements to ensure bespoke garment services can be incorporated into Pakistani fashion Industry for global services by evaluating post-use evaluation of the garment with 3D Body scanning. 
Furthermore, it is important to evaluate Level of acceptance of technology (innovativeness, usefulness, attitude, intended use, post use evaluation) by respondents as well as level of satisfaction with size and fit of a bespoke garment. The quantitative analysis has been discussed in this section.

\subsubsection{Technology Anxiety}

Responses to technology anxiety have been analysed, the reediness to use technology is an important factor to be measured to analyse attitude towards using technology. People feel fear and apprehension while thinking or actually using a technology. They might have a fear that the technology would not be well operated by them [63]-[64]. However, there are many online buyers who seek for new technology and explore novel practices that arouses their imagination [67]. Table 2 and fig 6 demonstrates the responses of consumers in context to technology anxiety towards 3D body scanning technology. Participants showed their interest in using latest technology for online shopping of customised garments. As it is established by Robinson in 2004 that innovativeness is construed as the acceptance of a user to try a novel technology [49]. $80 \%$ participants have disagreed with questions regarding technology anxiety that the technology terms are not confusing jargon to them. Therefore, they didn't avoid latest technology, they showed positive attitude to try a technology that benefit them for online bespoke shopping. Moreover, participants do not feel hesitant in using technology. Whereas (one participant) $20 \%$ respondents strongly agreed with feeling of fear and apprehension towards using 3D body scanning.

Table 2. Participants Response to Technology Anxiety towards 3D Body Scanning Technology

\begin{tabular}{|c|c|c|c|c|}
\hline \multicolumn{5}{|c|}{ Technical terms sound like confusing jargon to me } \\
\hline & Frequency & Percent & Valid Percent & $\begin{array}{c}\text { Cumulative } \\
\text { Percent }\end{array}$ \\
\hline Strongly Agree & 1 & 20.0 & 20.0 & 20.0 \\
\hline Somewhat Disagree & 2 & 40.0 & 40.0 & 60.0 \\
\hline Strongly Disagree & 2 & 40.0 & 40.0 & 100.0 \\
\hline Total & 5 & 100.0 & 100.0 & \\
\hline \multicolumn{5}{|c|}{ I have avoided technology because it is unfamiliar to me } \\
\hline & Frequency & Percent & Valid Percent & $\begin{array}{c}\text { Cumulative } \\
\text { Percent }\end{array}$ \\
\hline Strongly Agree & 1 & 20.0 & 20.0 & 20.0 \\
\hline Somewhat Disagree & 1 & 20.0 & 20.0 & 40.0 \\
\hline Disagree & 2 & 40.0 & 40.0 & 80.0 \\
\hline Strongly Disagree & 1 & 20.0 & 20.0 & 100.0 \\
\hline Total & 5 & 100.0 & 100.0 & \\
\hline \multicolumn{5}{|c|}{ I hesitate to use most froms of technology for fear of making mistakes I cannot correct } \\
\hline & Frequency & Percent & Valid Percent & $\begin{array}{c}\text { Cumulative } \\
\text { Percent }\end{array}$ \\
\hline Agree & 1 & 20.0 & 20.0 & 20.0 \\
\hline Somewhat Disagree & 2 & 40.0 & 40.0 & 60.0 \\
\hline Disagree & 1 & 20.0 & 20.0 & 80.0 \\
\hline Strongly Disagree & 1 & 20.0 & 20.0 & 100.0 \\
\hline Total & 5 & 100.0 & 100.0 & \\
\hline
\end{tabular}

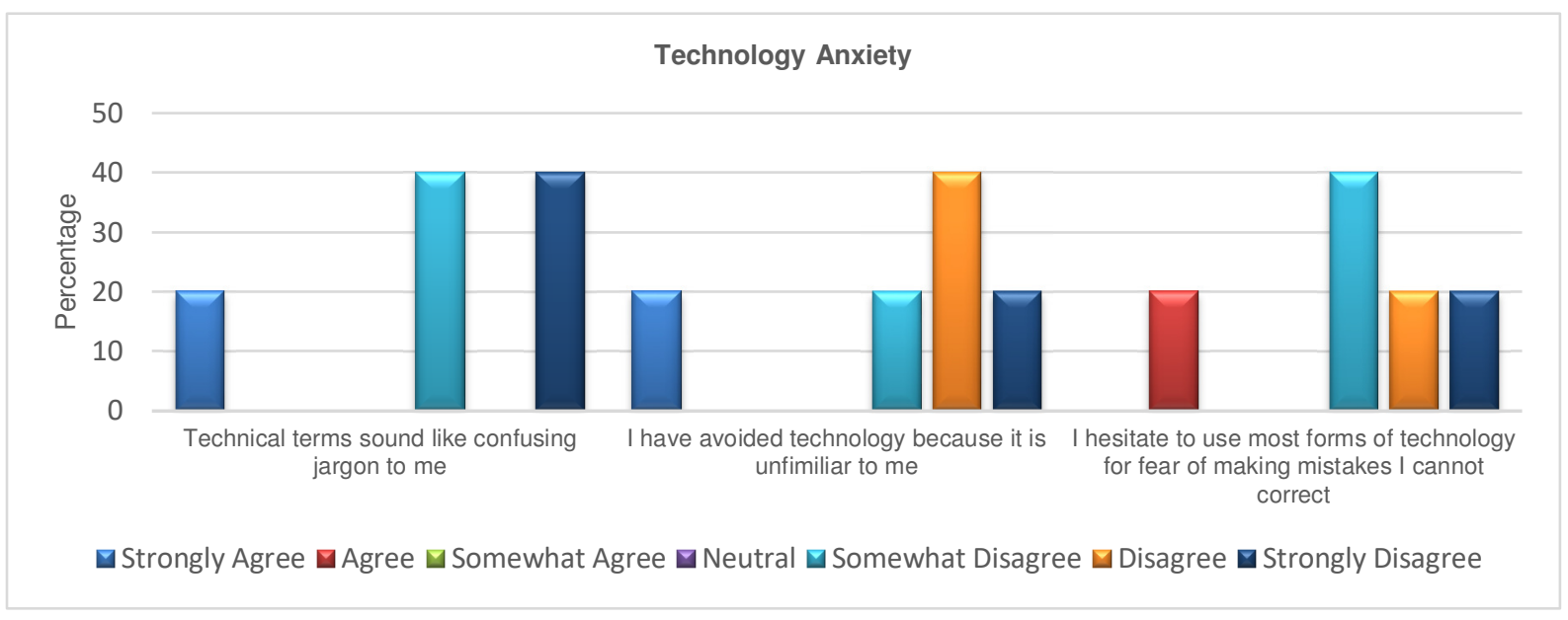

Fig. 6. Participants Response to Technology Anxiety towards 3D Body Scanning Technology 


\subsubsection{Perceived Usefulness}

Perceived usefulness implies consumer's reassurances and consumption of technology [68]. Perceived usefulness is explained as "the degree to which an individual believes that using a particular system would enhance his/her job performance" [53] p.320. Perceived usefulness and ease of use of technology can also affect the level of playfulness together, combining a relationship between functional and entertainment aspects of virtual size and fit technologies. Table 3 and Figure 7 shows the percentage of respondents towards perceived usefulness of technology. 100\% participants agreed that application is helpful for online bespoke garment shopping. It has increased the quality and makes them productive for online bespoke garment shopping. They have also agreed that application is reliable in terms of getting accurate body measurements and has improved the shopping ability of buying customised garments online.

Table 3. Participants Response to Perceived Usefulness towards 3D Body Scanning Technology

\begin{tabular}{|c|c|c|c|c|}
\hline \multicolumn{5}{|c|}{ I would find NETTELO application helpful when shopping online for bespoke garment } \\
\hline & Frequency & Percent & Valid Percent & $\begin{array}{l}\text { Cumulative } \\
\text { Percent }\end{array}$ \\
\hline Strongly Agree & 1 & 20.0 & 20.0 & 20.0 \\
\hline Agree & 1 & 20.0 & 20.0 & 40.0 \\
\hline Somewhat Agree & 3 & 60.0 & 60.0 & 100.0 \\
\hline Total & 5 & 100.0 & 100.0 & \\
\hline \multicolumn{5}{|c|}{ Use of NETTELO application could increase the quality of my online shopping of bespoke garment } \\
\hline & Frequency & Percent & Valid Percent & $\begin{array}{l}\text { Cumulative } \\
\text { Percent }\end{array}$ \\
\hline Strongly Agree & 1 & 20.0 & 20.0 & 20.0 \\
\hline Agree & 2 & 40.0 & 40.0 & 60.0 \\
\hline Somewhat Agree & 2 & 40.0 & 40.0 & 100.0 \\
\hline Total & 5 & 100.0 & 100.0 & \\
\hline \multicolumn{5}{|c|}{ Using NETTELO application measurements would make me more productive when shopping online } \\
\hline & Frequency & Percent & Valid Percent & $\begin{array}{l}\text { Cumulative } \\
\text { Percent }\end{array}$ \\
\hline Strongly Agree & 1 & 20.0 & 20.0 & 20.0 \\
\hline Agree & 2 & 40.0 & 40.0 & 60.0 \\
\hline Somewhat Agree & 2 & 40.0 & 40.0 & 100.0 \\
\hline Total & 5 & 100.0 & 100.0 & \\
\hline \multicolumn{5}{|c|}{$\begin{array}{c}\text { Using NETTELO 3D body scanning measurements would allow me the certainty of my body measurements for purchasing } \\
\text { online bespoke garments }\end{array}$} \\
\hline & Frequency & Percent & Valid Percent & $\begin{array}{l}\text { Cumulative } \\
\text { Percent }\end{array}$ \\
\hline Agree & 3 & 60.0 & 60.0 & 60.0 \\
\hline Somewhat Agree & 2 & 40.0 & 40.0 & 100.0 \\
\hline Total & 5 & 100.0 & 100.0 & \\
\hline \multicolumn{5}{|c|}{ Using NETTELO 3D body scanning measurements would improve my online shopping ability of bespoke garments } \\
\hline & Frequency & Percent & Valid Percent & $\begin{array}{l}\text { Cumulative } \\
\text { Percent }\end{array}$ \\
\hline Strongly Agree & 1 & 20.0 & 20.0 & 20.0 \\
\hline Agree & 2 & 40.0 & 40.0 & 60.0 \\
\hline Somewhat Agree & 2 & 40.0 & 40.0 & 100.0 \\
\hline Total & 5 & 100.0 & 100.0 & \\
\hline
\end{tabular}




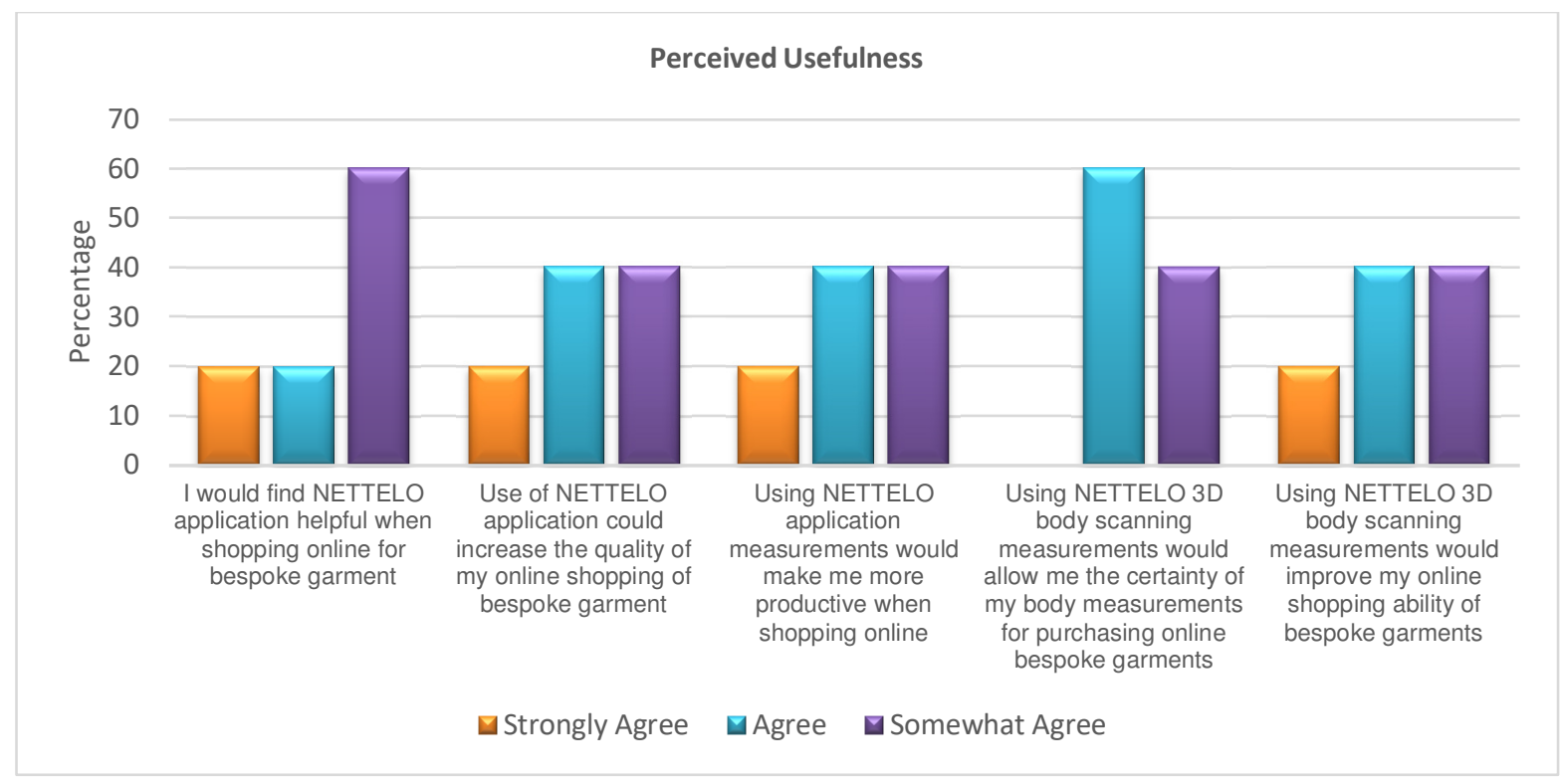

Fig. 7. Participants Response to Perceived Usefulness towards 3D Body Scanning Technology

\subsubsection{Perceived Ease of Use}

Prior studies have established that ease of use in a vital element in envisaging attitudes towards technology adoption self-service [69], [56], [58]. Rogers (1995) [45], revealed that intricacy, the reverse of ease of use [70], decreases consumer's readiness to espouse a new technology. Therefore, the effortless the technology is to use, it will be perceived to be more practical [58]. Table 4 figure 8 revealed that $40 \%$ and $60 \%$ participants are strongly agreed and somewhat agreed that the application is clear and understandable. However, $100 \%$ participants showed a negative response to technology while using it because it requires great mental effort in extracting digital measurements. The users have to create body silhouette after taking front and side view photos, which required effort, time and needs accuracy in silhouette creation for extracting digital measurements. Therefore, participants revealed that the application is not easy to use.

Table 4. Participants Response to Perceived Ease of Use towards 3D Body Scanning Technology

\begin{tabular}{|c|c|c|c|c|}
\hline \multicolumn{5}{|c|}{ Using NETTELO 3D body scanning application is clear and understandable } \\
\hline & Frequency & Percent & Valid Percent & $\begin{array}{l}\text { Cumulative } \\
\text { Percent }\end{array}$ \\
\hline Strongly Agree & 2 & 40.0 & 40.0 & 40.0 \\
\hline Somewhat Agree & 3 & 60.0 & 60.0 & 100.0 \\
\hline Total & 5 & 100.0 & 100.0 & \\
\hline \multicolumn{5}{|c|}{ Using NETTELO 3D body scanning mobile application doesn't require much more mental effort for extraction of my body measurements } \\
\hline & Frequency & Percent & Valid Percent & $\begin{array}{l}\text { Cumulative } \\
\text { Percent }\end{array}$ \\
\hline Somewhat Disagree & 2 & 40.0 & 40.0 & 40.0 \\
\hline Disagree & 2 & 40.0 & 40.0 & 80.0 \\
\hline Strongly Disagree & 1 & 20.0 & 20.0 & 100.0 \\
\hline Total & 5 & 100.0 & 100.0 & \\
\hline \multicolumn{5}{|c|}{ NETTELO 3D body scanning application is easy to use } \\
\hline & Frequency & Percent & Valid Percent & $\begin{array}{c}\text { Cumulative } \\
\text { Percent }\end{array}$ \\
\hline Somewhat Disagree & 1 & 20.0 & 20.0 & 20.0 \\
\hline Disagree & 3 & 60.0 & 60.0 & 80.0 \\
\hline Strongly Disagree & 1 & 20.0 & 20.0 & 100.0 \\
\hline Total & 5 & 100.0 & 100.0 & \\
\hline
\end{tabular}




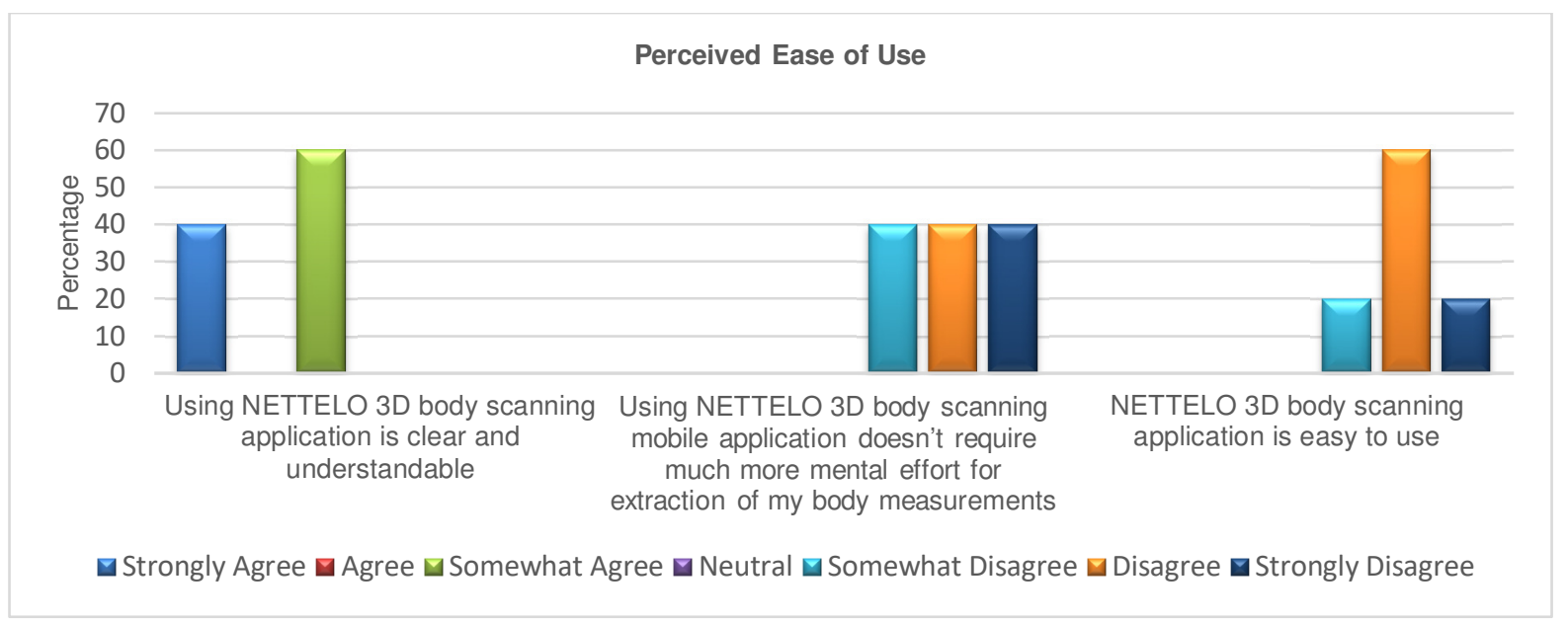

Fig. 8. Participants Response to Perceived Ease of Use towards 3D Body Scanning Technology

\subsubsection{Perceived Entertainment Value}

Perceived entertainment value is defined as the consumer's capability to react promptly, ingeniously and extravagantly with a computer or interface [71]. Formerly experimental studies have explored Playfulness, enjoyment and entertainment value of a technology [72]-[76]. Huang and Liao (2015) [77] appraised the impact of entertainment on augmented reality technology. Similarly [74] have also studied the entertainment value of Virtual try-on technology and concluded as strong analysts of attitudes towards utilising Virtual Try-on for both men and women. Table 5 and Figure 9 demonstrates that $40 \%$ participants agreed that using application is fun due to negative impact on perceived ease of use and effort required while using it. However, $20 \%$ participants found the application enjoyable in terms of getting digital measurements. Whereas $40 \%$ participants did not find it enjoyable. $60 \%$ participants respond that application has aroused their imagination and $80 \%$ participants are curious to use technology, as they are surprised on getting digital measurements using a mobile application.

Table 5. Participants Response to Perceived Entertainment Value towards 3D Body Scanning Technology

\begin{tabular}{|c|c|c|c|c|}
\hline \multicolumn{5}{|c|}{ Using NETTELO 3D Body Scanning mobile application is fun } \\
\hline & Frequency & Percent & Valid Percent & $\begin{array}{c}\text { Cumulative } \\
\text { Percent }\end{array}$ \\
\hline Agree & 2 & 40.0 & 40.0 & 40.0 \\
\hline Neutral & 1 & 20.0 & 20.0 & 60.0 \\
\hline Somewhat Disagree & 2 & 40.0 & 40,0 & 100.0 \\
\hline Total & 5 & 100.0 & 100.0 & \\
\hline \multicolumn{5}{|c|}{ Using NETTELO 3D body scanning mobile application is enjoyable } \\
\hline & Frequency & Percent & Valid Percent & $\begin{array}{c}\text { Cumulative } \\
\text { Percent }\end{array}$ \\
\hline Strongly Agree & 1 & 20.0 & 20.0 & 20.0 \\
\hline Somewhat Agree & 1 & 20.0 & 20.0 & 40.0 \\
\hline Neutral & 1 & 20.0 & 20.0 & 60.0 \\
\hline Somewhat Disagree & 2 & 40.0 & 40.0 & 100.0 \\
\hline Total & 5 & 100.0 & 100.0 & \\
\hline \multicolumn{5}{|c|}{ NETTELO 3D body scanning application arouses my imagination } \\
\hline & Frequency & Percent & Valid Percent & $\begin{array}{c}\text { Cumulative } \\
\text { Percent }\end{array}$ \\
\hline Somewhat Agree & 3 & 60.0 & 60.0 & 60.0 \\
\hline Neutral & 2 & 40.0 & 40.0 & 100.0 \\
\hline Total & 5 & 100.0 & 100.0 & \\
\hline \multicolumn{5}{|c|}{ Using NETTELO 3D body scanning mobile application stimulates my curiosity } \\
\hline & Frequency & Percent & Valid Percent & $\begin{array}{c}\text { Cumulative } \\
\text { Percent }\end{array}$ \\
\hline Agree & 4 & 80.0 & 80.0 & 80.0 \\
\hline Somewhat Agree & 1 & 20.0 & 20.0 & 100.0 \\
\hline Total & 5 & 100.0 & 100.0 & \\
\hline
\end{tabular}




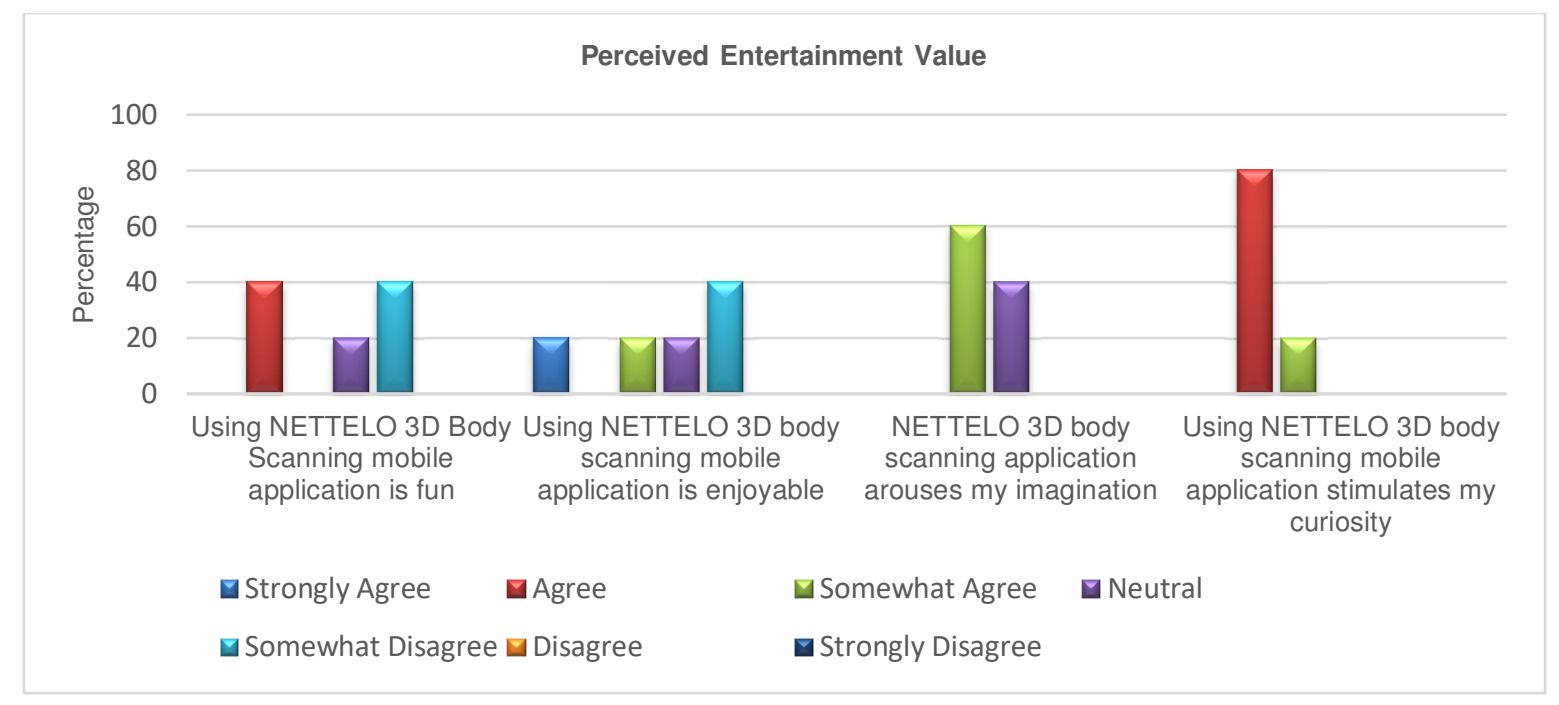

Fig. 9. Participants Response to Perceived Entertainment Value towards 3D Body Scanning Technology

\subsubsection{Attitude}

The studies on innovation clarifies that a user's attitude towards employing an innovation encourages acceptance of the innovation [45]. Thus, a consumer's technology employment is a function of his or her intention to utilise a system [78]. The TAM theoretical model is based on theory of reasoned action, established that higher the positive attitude towards performing a conduct, the more likely a user is to accomplish that conduct [79]. Users with positive attitudes for shopping online are less likely to abandon planned transactions [80]. The attitude of respondents has been collected with rating scale with 1 to 7 . Where 1-3 shows positive attitude 4 neutral and 5-7 shows negative attitude towards using a technology. Table 6 and Figure 10 demonstrates that using 3D body scanning technology is a good idea and finds it superior to manual measurements methods. $40 \%$ respondents gave the rating scale 4 , they showed neutral and negative response and found application unpleasant. However, they found it appealing and excellent in terms of usefulness, as it is an excellent introductory platform for online bespoke garment shopping. 
Table 6. Participants Response to Attitude towards 3D Body Scanning Technology

\begin{tabular}{|c|c|c|c|c|}
\hline \multicolumn{5}{|c|}{ Using NETTELO 3D Body Scanning mobile application is ......A good Idea 1 - A bad idea } \\
\hline & Frequency & Percent & Valid Percent & $\begin{array}{l}\text { Cumulative } \\
\text { Percent }\end{array}$ \\
\hline A good idea 1 & 1 & 20.0 & 20.0 & 20.0 \\
\hline 2 & 2 & 40.0 & 40.0 & 60.0 \\
\hline 3 & 2 & 40.0 & 40,0 & 100.0 \\
\hline Total & 5 & 100.0 & 100.0 & \\
\hline \multicolumn{5}{|c|}{$\begin{array}{l}\text { Using NETTELO 3D body scanning mobile application is } \\
\text { human measurements extraction } 1 \text { - Inferior to manual method of human measurements } \\
\text { extraction } 7\end{array}$} \\
\hline & Frequency & Percent & Valid Percent & $\begin{array}{c}\text { Cumulative } \\
\text { Percent }\end{array}$ \\
\hline $\begin{array}{l}\text { Superior to manual method } \\
\text { of human measurements } \\
\text { extraction } 1\end{array}$ & 1 & 20.0 & 20.0 & 20.0 \\
\hline 2 & 3 & 60.0 & 60.0 & 80.0 \\
\hline 3 & 1 & 20.0 & 20.0 & 60.0 \\
\hline Total & 5 & 100.0 & 100.0 & \\
\hline \multicolumn{5}{|c|}{ Using NETTELO 3D body scanning application is......Pleasant 1 - Unpleasant 7} \\
\hline & Frequency & Percent & Valid Percent & $\begin{array}{l}\text { Cumulative } \\
\text { Percent }\end{array}$ \\
\hline Pleasant 1 & 1 & 20.0 & 20.0 & 20.0 \\
\hline 4 & 2 & 40.0 & 40.0 & 60.0 \\
\hline 5 & 1 & 20.0 & 20.0 & 80.0 \\
\hline 6 & 1 & 20.0 & 20.0 & 100.0 \\
\hline Total & 5 & 100.0 & 100.0 & \\
\hline \multicolumn{5}{|c|}{ Using NETTELO 3D body scanning mobile application is......Appealing 1 - Unappealing 7} \\
\hline & Frequency & Percent & Valid Percent & $\begin{array}{c}\text { Cumulative } \\
\text { Percent }\end{array}$ \\
\hline Appealing 1 & 1 & 20.0 & 20.0 & 20.0 \\
\hline 3 & 2 & 40.0 & 40.0 & 60.0 \\
\hline 4 & 1 & 20.0 & 20.0 & 80.0 \\
\hline 5 & 1 & 20.0 & 20.0 & 100.0 \\
\hline Total & 5 & 100.0 & 100.0 & \\
\hline \multicolumn{5}{|c|}{ Using NETTELO 3D body scanning mobile application is..... Excellent $1-$ Poor 7} \\
\hline & Frequency & Percent & Valid Percent & $\begin{array}{c}\text { Cumulative } \\
\text { Percent }\end{array}$ \\
\hline Excellent 1 & 1 & 20,0 & 20,0 & 20.0 \\
\hline 3 & 2 & 40.0 & 40.0 & 60.0 \\
\hline 4 & 1 & 20.0 & 20.0 & 80.0 \\
\hline 5 & 1 & 20.0 & 20.0 & 100.0 \\
\hline Total & 5 & 100.0 & 100.0 & \\
\hline
\end{tabular}




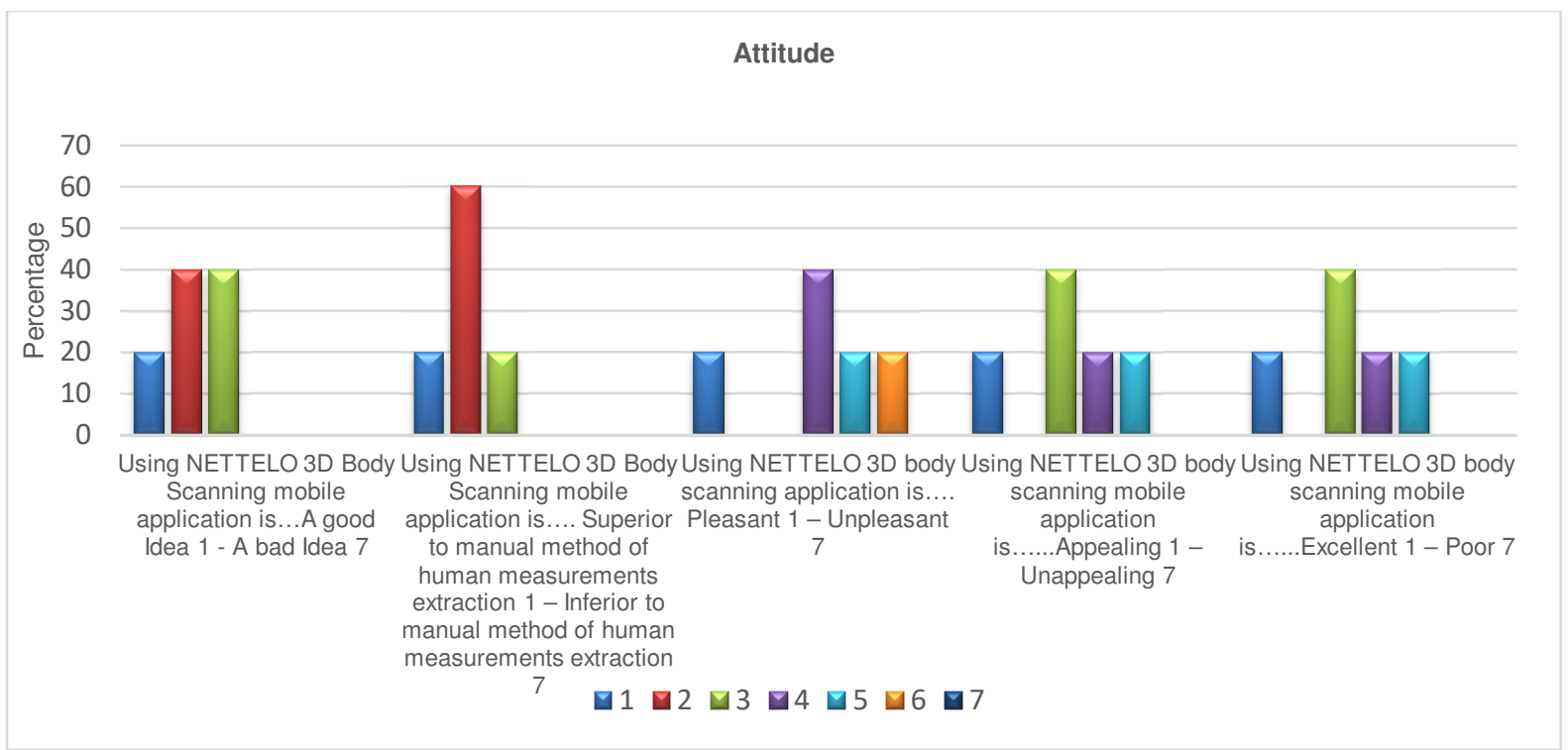

Fig. 10. Participants Response to Attitude towards 3D Body Scanning Technology

\subsubsection{Intended Use}

Former studies established a strong pragmatic sustenance for an optimistic association between perceived ease of use and perceived usefulness [53], [81], [82]. Therefore, the effortless the technology is to use, it will be perceived to be more practical [58]. The intention to use technology is based on ease of use and usefulness of technology. Moreover, if the technology is useful in terms of what it claims for the users will showed positive intention in using technology. However, if technology requires more effort in using it then it would have a negative impact on intended use. Table 7 and Figure 11 demonstrate that $60 \%$ users showed positive response on using and visiting Nettelo and similar 3D body scanning applications in future for online shopping of bespoke garments. $60 \%$ respondents were dissatisfied with size and fit, as it is slightly loose fitted garments. However, respondents showed positive response for addition of 3D body scanning tool in fashion e-commerce platform for effective selection of right fitted garment and customisation of garment.

Table 7. Participants Response to Intention to use 3D Body Scanning Technology

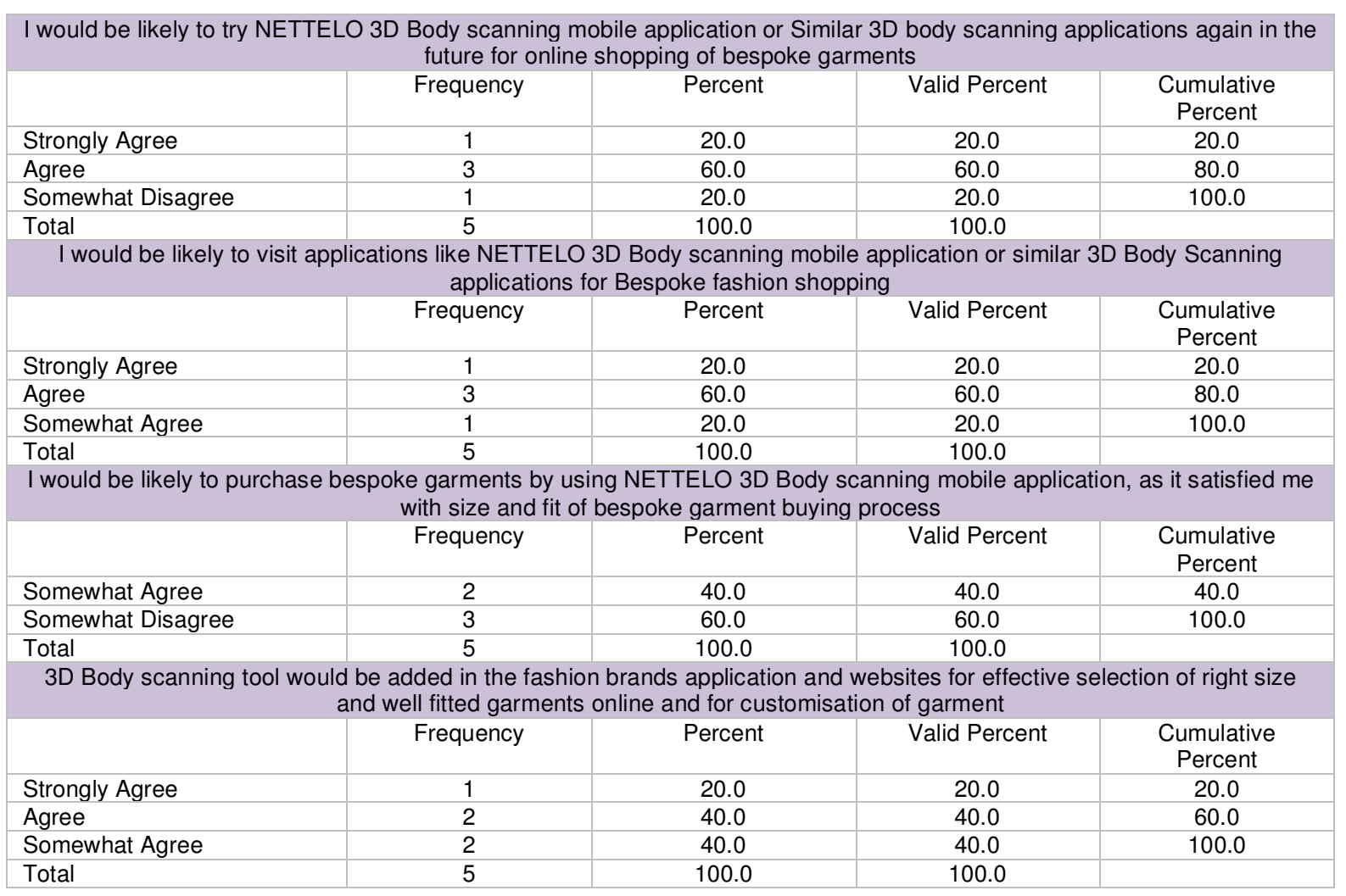




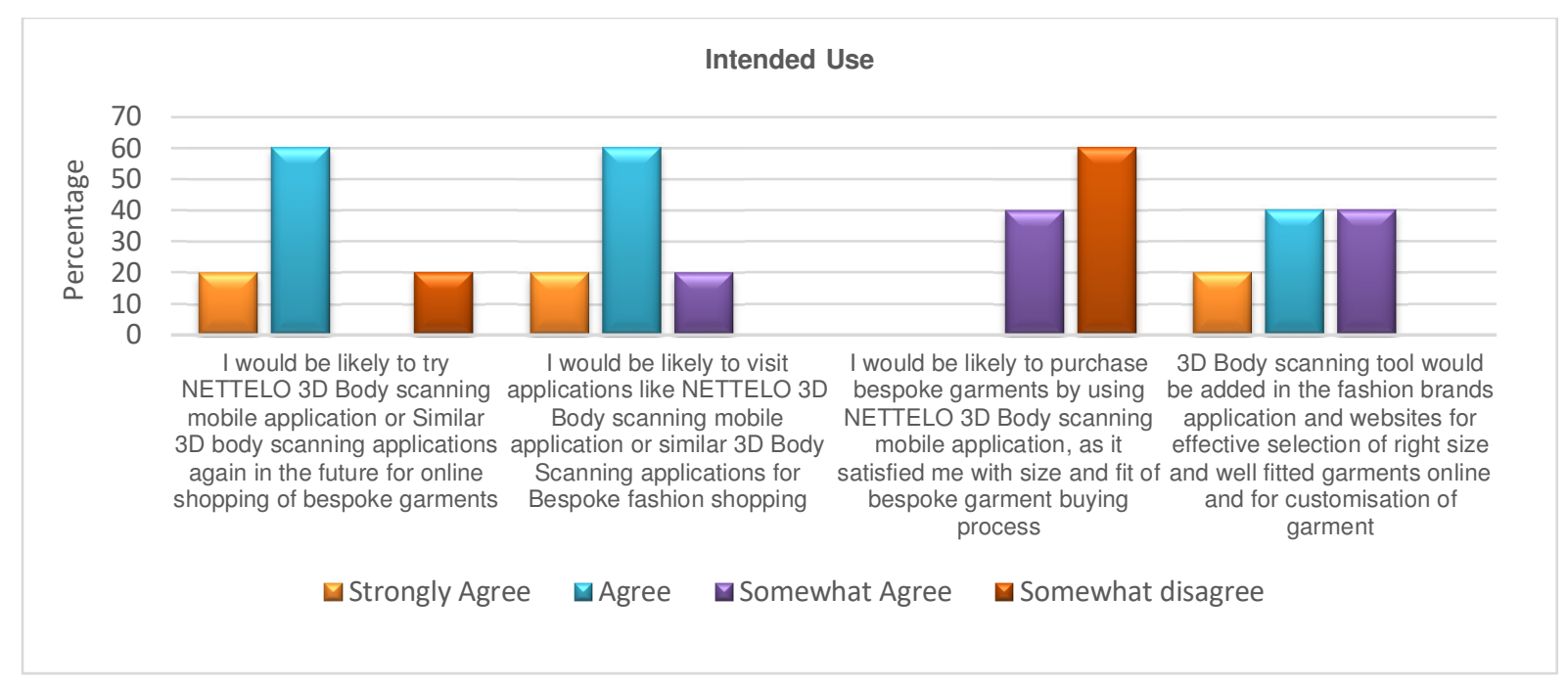

Fig. 11. Participants Response to Intention to use 3D Body Scanning Technology

\subsection{Qualitative Data Analysis}

To study post use evaluation, the participants responded to open ended questionnaire for holistic understanding about their views on size and fit of bespoke garment after trying on. 1) Fit satisfaction: Respondents had similar experience about fit satisfaction. Although, all of them are satisfied found it relaxed fit and easy to carry around, they want their garments altered and stitched 2 inches tight then it would be their perfect fit. 2) Fit expectation with 3D body scanning process: One respondent is quite happier with the garments fitting especially her trouser fitting is much better than the bespoke trouser she normally wears because she is comfortable with a little loose garment. Another respondent wasn't sure with application would be able to deliver accurate measurements and she was surprised on having near to right size measurement, she also added that the application mechanism can be improved to get exact right size garment because she found her garment 3 to $4 \mathrm{~cm}$ loose. Another participant was quite happy with the size and fit of the garment and she was surprised too with accuracy of mobile application. Another two participants were not satisfied because the garment was loose and expected better fit. 3) Similar areas comparative fit: Two participants were satisfied because she found the garment perfectly fit because she doesn't wear slim fit garments. Three of them were a bit unsatisfied because the garment was loose fit, and it should be slim fit. 4) Length: Participants found the length of garment Perfect. 5) Style: The participants were given traditional Kameez and trouser worn by Pakistani female. Trouser is selected for study because it is a slim fit garment style. Thus, to understand the accuracy of technology in terms of size and fit. Whereas, Shalwar has a loose fitted garment style. Therefore, the participants were happy with the style. 6) Purchase Intention: Four participants showed intention to keep the garment either it is loose fit. However, one participant intends to buy a better fitted garment. 7) Future use: The participants are happy with the novel technology and they want 3D body scanning tool to be added in the fashion e-commerce platforms for future online purchase of bespoke garments. 8) Post use evaluation (any other comments): In their additional comments they recommended that application is useful, but it should be more user friendly. The application is extracting almost 3-4 cm bigger measurements than actual body measurement. Overall, they found the application experience was useful and informative too.

\section{Discussion}

The present study explored Pakistani female consumers' experience using 3D body scanning technology and their acceptance level of application to adopt for bespoke apparel online shopping. Results indicated that, females are interested in using technology, they are curious to use scanning tool to view their digital measurements and they are surprised with the results by using a mobile application. Although the respondents in this study have strong positive responses towards the scanning experience, the majority found that application requires effort and time, as they have to create their body silhouette to extract measurements. The researcher too puts effort by conducting a zoom conference to give them instructions on using application to get accurate results. The perceived ease of use has strong impact on attitude and intention to use technology. However, they showed positive response on using similar effortless 3D body scanning technology. Moreover, the female participants were comfortable on using application because they performed the task at home in their room with the 
help of family member, they feel comfortable with. Regarding application usefulness the female found it useful because Pakistani consumers frequently buy unstitched fabric for bespoke garment construction. Although they are comfortable with their size as they wear which is slightly loose fit garment, they noted that the application measurements are almost 3 to $4 \mathrm{~cm}$ bigger than the measurements they themselves extracted manually by tape measurement method. The participants are unaware that they are not taking measurements the same way as the scanning tool. Although, there is a possibility of scanning tool presenting bigger measurements, the participants are distrusting the application too because when they check the measurements against the application, and they found it different. They don't recognise that they might not taking the same measurements (landmarking points) as the tool did or might they use the tape measurement very tight and manual measurements are smaller. Therefore, they have highlighted the area of contention, because it might be the measurements are right, but the manual measurements aren't taken in the right way. The app-developers and software engineers may get benefit with application acceptance on trying to build more confidence in the user, explaining how to extract measurements then the error would be acceptable. The problem is that the participants built distrust with the application and it might lead to the tool not being used. However, participants added that the idea of getting digital measurements is superior than manual measurements method and quite useful in terms of online shopping as it saves lot of time and effort. Moreover, participants found the additional feature of size recommendation very useful tool for ready to wear online shopping. They highlighted that to size recommendation tool should also be added in the e-commerce website of Pakistan. The study finding is associated with [83]-[85], where 3D scanning technology in the fashion e-commerce context are perceived as a novel approach that can lessen apparel fit dissatisfaction. Consequently, it can be concluded that Pakistani female consumers have a positive attitude towards the scanning process and are interested to use the 3D body scanning applications for bespoke apparel purchase using fashion e-commerce environments, yet they highlighted difficulty in using the technology and for these technologies to be successful they need to be easily utilised and user testing is necessary with clearer instructions. Otherwise there is obviously user experience issues with the interface. The app-developers should consider the easier mechanism, easy would be to pick up and go with it. Therefore, It is necessary to work with users to ensure how exactly to get the right data. A great tool with wrong data is not particularly useful. This technology paves the way for online apparel retailers to get benefit establishing globalise business. The 3D body scanning has a potential to be added in the e-commerce platforms which can also be useful in Virtual try-on simulations for ready to wear and mass-customisation, this can lead to the incorporation of operative marketing and merchandising strategies.

\section{Conclusion}

Artificial intelligence and machine learning have introduced web 3.0 technology feature such as 3D body scanning and Virtual trying on simulations. Earlier 3D body scanners are not accessible to common and unprofessional users. Now with the rapid advancement in technology, mobile body scanning makes the technology available and accessible to users sometimes at no cost. This study paves the way for Pakistani (Unstitched Apparel Industry) bespoke fashion brands, small medium enterprises and international companies to utilise such technologies in future with amalgamation of Virtual Fit platform and 3D Body Scanning may integrate with such ergonomic prediction tools for Pakistani fashion e-commerce platforms. The main contribution of this study is to understand the mechanism of prevailing application and to explore the potential and accuracy of 3D Body Scanning tool offered to consumers to be used at home for size recommendation and garment customisation. The Nettelo 3D body scanning technology offers size recommendation for ready to wear garments. Consumer can get size advice with major international sizing system such as (US, UK, FR, IT, DE). This approach would lead to more precise Virtual try-on simulation on personalise body Avatars in fashion e-commerce platforms. This technology would allow fashion designers and retailers to enhance Industry to more automated and precise systems of mass customisation, virtual tailoring and size recommendation system for ready to wear. As the benefits of 3D Body Scanning for fit analysis established more appreciation, the technology will subsidise to better fitting garments. 3D Body Scanning should also lead to and advanced e-commerce success through reducing return rates and more competent supply chain management. However, there remain some limitations in the technology particularly participants highlighted difficulty in using technology and researcher noticed the conflict between the acceptance of data that tool provided against the consumer checking the mechanism for ensuring it accurate. 


\section{References}

[1] A. Clarke-Sather and K. Cobb, "Onshoring fashion: Worker sustainability impacts of global and local apparel production," J. Clean. Prod., vol. 208, pp. 1206-1218, 2019.

[2] M. Kumar and A. Walia, "Elucidation of the Indian Salwar Kameez," IJASOS- Int. E-journal Adv. Soc. Sci., vol. II, no. 6, pp. 753-753, 2017.

[3] C. Mair, "The Psychology of Fashion. Routledge.," 2018.

[4] S. Ballester, A., Parrilla, E., Piérola, A., Uriel, J., Pérez, C., Piqueras, P., Nácher, B., Vivas, J.A. and Alemany, "Data-driven three-dimensional reconstruction of human bodies using a mobile phone app," Int. J. Digit. Hum., vol. 1, no. 4, p. 361, 2016.

[5] M. E. Bradtmiller,B. and Gross, "3D Whole Body Scans: Measurement Extraction Software Validation," SAE Trans., vol. 108, pp. 394-400, 1999.

[6] L. D. Dekker, "3D human body modelling from range data' PhD thesis, Doctoral dissertation,University of London, London, United Kingdom.," 2000.

[7] J. M. Lu and M. J. J. Wang, "The evaluation of scan-derived anthropometric measurements," IEEE Trans. Instrum. Meas., vol. 59, no. 8, pp. 2048-2054, 2010.

[8] K. M. Robinette and H. A. M. Daanen, "Precision of the CAESAR scan-extracted measurements," Appl. Ergon., vol. 37, no. 3, pp. 259-265, 2006.

[9] A. J. Latham, "Markets and development in Africa and Asia," in The Market in History (Routledge Revivals), Routledge, 2016, pp. 211-230.

[10] Y. Hong, P. Bruniaux, X. Zeng, A. Curteza, and K. Liu, "Design and evaluation of personalized garment block for atypical morphology using the knowledge-supported virtual simulation method," Text. Res. J., vol. 88, no. 15, pp. 1721-1734, 2018.

[11] B. L. Zeng, J., Simpson, C.G. and Dang, "Model of Dynamic Capability Development: Evidence from the Chinese Manufacturing Sector.," Manag. Organ. Rev., vol. 13, no. 3, pp. 643-673, 2017.

[12] C.-M. Chen, "Fit evaluation within the made-to-measure process.," Int. J. Cloth. Sci. Technol., vol. 19, no. 2, pp. 131-144, 2007.

[13] S. Brownbridge, K., Sanderson, R., \& Gill, "Aspirational bodies: Fashioning new beauty ideals.," Inter-disciplinary.net, pp. 1-12, 2016.

[14] K. Klepp, I.G. and Laitala, "Nisseluelandet-The Impact of Local Clothes for the Survival of a Textile Industry in Norway," Fash. Pract., vol. 10, no. 2, pp. 171-195, 2018.

[15] U. Amir, S., Kotikula, A., Pande, R.P., Bossavie, L.L.Y. and Khadka, "Female Labor Force Participation in Pakistan: What Do We Know?," 2018.

[16] P. R. Apeagyei, "Application of 3D body scanning technology to human measurement for clothing fit," Int. J. Digit. Content Technol. its Appl., vol. 4, no. 7, pp. 2-9, 2010.

[17] E. A. Gribbins, "Body shape and its influence on apparel size and consumer choice. In M.-E. Faust \& S. Carrier (Eds.)," in Designing apparel for consumer: The impact of body shape and size, Cambridge: Woodhead Publishing Series in Textiles., 2014, pp. 3-16.

[18] H. A. M. Daanen and F. B. Ter Haar, "3D whole body scanners revisited," Displays, vol. 34, no. 4, pp. 270-275, 2013.

[19] L. Dekker, I. Douros, B. F. Buston, and P. Treleaven, "Building symbolic information for 3D human body modeling from range data," Proc. - 2nd Int. Conf. 3-D Digit. Imaging Model. 3DIM 1999, pp. 388-397, 1999.

[20] N. D'Apuzzo, "Overview of 3D surface digitization technologies in Europe," Three-Dimensional Image Capture Appl. VII, vol. 6056, p. 605605, 2006.

[21] J. Der Lin, W. K. Chiou, H. F. Weng, Y. H. Tsai, and T. H. Liu, "Comparison of three-dimensional anthropometric body surface scanning to waist-hip ratio and body mass index in correlation with metabolic risk factors," J. Clin. Epidemiol., vol. 55, no. 8, pp. 757-766, 2002.

[22] P. Treleaven and J. Wells, "3D body scanning and healthcare applications," Computer (Long. Beach. Calif)., vol. 40, no. 7, pp. 28-34, 2007.

[23] J. Wang, D. Gallagher, J. C. Thornton, W. Yu, M. Horlick, and F. X. Pi-Sunyer, "Validation of a 3-dimensional photonic scanner for the measurement of body volumes, dimensions, and percentage body fat," Am. J. Clin. Nutr., vol. 83, no. 4, pp. 809-816, 2006. 
[24] S. Gill, "A review of research and innovation in garment sizing, prototyping and fitting," Text. Prog., vol. 47, no. 1, pp. 1-85, 2015.

[25] H. A. M. Daanen and G. J. Van De Water, "Whole body scanners," Displays, vol. 19, no. 3, pp. 111-120, 1998.

[26] S. Idrees, G. Vignali, and S. Gill, "Technological Advancement in Fashion Online Retailing: A Comparative Study of Pakistan and UK Fashion E-Commerce," vol. 14, no. 4, pp. 318-333, 2020.

[27] S. Charoensiriwath and C. Tanprasert, "An Overview of 3D Body Scanning Applications in Thailand," no. October, pp. 158-165, 2010.

[28] J. M. Sohn, S. Lee, and D. E. Kim, "An exploratory study of fit and size issues with mass customized men's jackets using 3D body scan and virtual try-on technology," Text. Res. J., 2020.

[29] L. D. Romeo et al., "2017 Proceedings," vol. m, pp. 2-3, 2017.

[30] J. P. Bougourd, L. Dekker, P. G. Ross, and J. P. Ward, "A Comparison of Women's Sizing by 3D Electronic Scanning and Traditional Anthropometry," J. Text. Inst., vol. 91, no. 2, pp. 163173, 2000.

[31] R. Pandarum, W. Yu, and L. Hunter, "3-D breast anthropometry of plus-sized women in South Africa," Ergonomics, vol. 54, no. 9, pp. 866-875, 2011.

[32] H. Han and Y. Nam, "Automatic body landmark identification for various body figures," Int. J. Ind. Ergon., vol. 41, no. 6, pp. 592-606, 2011.

[33] G. Vignali, L. F. Reid, D. Ryding, and C. E. Henninger, Technology-Driven Sustainability. 2020.

[34] S. P. Ashdown and H. Na, "Comparison of 3-D body scan data to quantify upper-body postural variation in older and younger women," Cloth. Text. Res. J., vol. 26, no. 4, pp. 292-307, 2008.

[35] S. Gill, C. J. Parker, S. Hayes, K. Brownbridge, P. Wren, and A. Panchenko, "The True Height of the Waist: Explorations of Automated Body Scanner Waist Definitions of the TC2 scanner," no. October, pp. 55-65, 2014.

[36] S. Gill and N. Chadwick, "Determination of ease allowances included in pattern construction methods," Int. J. Fash. Des. Technol. Educ., vol. 2, no. 1, pp. 23-31, 2009.

[37] S. GILL, M. AHMED, C. J. PARKER, and S. G. HAYES, "Not All Body Scanning Measurements Are Valid: Perspectives from Pattern Practice," no. October, pp. 43-52, 2017.

[38] ISO, "International Organization for Standardization, Size designation of clothes - Part 1: Anthropometric definitions for body measurement," Iso 8559-12017, p. 80, 2017.

[39] "Sapphire," 2019. [Online]. Available: https://pk.sapphireonline.pk/. [Accessed: 04-Dec-2019].

[40] J. Harris, Textiles, 5,000 years: an international history and illustrated survey. 1995.

[41] M. Afreen and P. Haq, "Differences in girth measurement of BMl based and locally avaliable categories of shirt sizes," Nurture, vol. 11, no. 1, 2017.

[42] R. Nayak and R. Padhye, "The use of laser in garment manufacturing: an overview," Fash. Text., vol. 3, no. 1, 2016.

[43] K. Noh, M., Carroll, J., Holt, S. and Blaser, "Fast and Slow Fashion Brands in Developing Sustainable Fashion: Aspect of Fiber Materials," 2017 Glob. Fash. Manag. Conf. Vienna, pp. 439-444, 2017.

[44] E. Saeidi and V. S. Wimberley, "Precious cut: exploring creative pattern cutting and draping for zero-waste design," Int. J. Fash. Des. Technol. Educ., vol. 11, no. 2, pp. 243-253, 2018.

[45] E. M. Rogers, Diffusion of Innovations.4th ed. New York: Free Press. 1995.

[46] L. P. Venkatraman, M. P., and Price, "Differentiating between cognitive and sensory innovativeness: Concepts, measurement, and their implications.," J. Bus. Res., vol. 20, pp. 293315, 1990.

[47] S. W. Meuter, M. L., Bitner, M. J., Ostrom, A. L., \& Brown, "Choosing among alternative service delivery modes: An investigation of customer trial of self-service technologies.," J. Mark., vol. 69, pp. 50-65, 2005.

[48] M. L. Meuter, A. L. Ostrom, M. J. Bitner, and R. Roundtree, "The influence of technology anxiety on consumer use and experiences with self-service technologies," J. Bus. Res., vol. 56, no. 11, pp. 899-906, 2003.

[49] M. B. Robinson, L., Jr., Marshall, G. W., and Stamps, "Sales force use of technology: Antecedents to technology acceptance.," J. Bus. Res., vol. 58, pp. 1623-1631, 2004. 
[50] T. Peck, J., \& Childers, "Individual differences in haptic information processing: The 'need for touch' scale.," J. Consum. Res., vol. 30, pp. 430-442, 2004.

[51] T. P. Hoffman, D. L., and Novak, "Marketing in hypermedia computer-mediated environments: Conceptual foundations.," J. Mark., vol. 60, pp. 50-68, 1996.

[52] P. Y. K. Chau, "An Empirical Assessment of a Modified Technology Acceptance Model," J. Manag. Inf. Syst., vol. 13, pp. 185-204, 1996.

[53] F. D. Davis, "Perceived usefulness, perceived ease of use, and user acceptance of information technology," MIS Q. Manag. Inf. Syst., vol. 13, no. 3, pp. 319-339, 1989.

[54] P. A. Pavlou, "Consumer acceptance of electronic commerce: Integrating trust and risk with the technology acceptance model.," Int. J. Electron. Commer., vol. 7, pp. 69-103, 2003.

[55] P. Taylor, S., and Todd, "Assessing IT usage: The role of prior experience," MIS Q., vol. 19, pp. 57-561, 1995.

[56] P. R. Davis, F. D., Bagozzi, R. P., and Warshaw, "Extrinsic and intrinsic motivation to use computers in the workplace.," J. Appl. Soc. Psychol., vol. 22, pp. 1111-1132, 1992.

[57] H. Heijden, "User acceptance of hedonic information systems.," MIS Q., vol. 28, pp. 695-704, 2004.

[58] H. Heijden, "E-TAM: A revision of the technology acceptance model to explain websites revisits.," Res. Memo. Sept., 2000.

[59] M. Babin, B. J., Darden, W. R., \& Griffen, "Work and/or fun: measuring hedonic and utilitarian shopping value.," J. Consum. Res., vol. 20, pp. 644-656, 1994.

[60] T. L. Childers, C. L. Carr, J. Peck, and S. Carson, "Hedonic and utilitarian motivations for online retail shopping behavior," J. Retail., vol. 77, no. 4, pp. 511-535, 2001.

[61] P. R. Easterby-Smith, M., Thorpe, R. and Jackson, "Management and business research. Sage.," 2015.

[62] L. Martin, J., Mortimer, G. and Andrews, "Re-examining online customer experience to include purchase frequency and perceived risk," J. Retail. Consum. Serv., vol. 25, pp. 81-95, 2015.

[63] D. L. Cambre, M.A. and Cook, "Computer anxiety: Definition, measurement, and correlates.," J. Educ. Comput. Res., vol. 1, no. 1, pp. 37-54, 1985.

[64] S. C. Scott, C. R., and Rockwell, "The effect of communication, writing, and technology apprehension on likelihood to use new communication technologies.," Commun. Educ., vol. 46, pp. 44-62, 1997.

[65] R. Meuter, M. L., Ostrom, A. L., Bitner, M. J., \& Roundtree, "The influence of technology anxiety on consumer use and experiences with self-service technologies.," J. Bus. Res., vol. 56, pp. 899-906, 2003.

[66] R. A. Westbrook, "A rating scale for measuring product/ service satisfaction.," J. Mark., vol. 44, pp. 68-72, 1980.

[67] E. C. Hirschman, "Experience seeking: A subjectivistic perception of consumption.," J. Bus. Res., vol. 12, pp. 115-136, 1984.

[68] J. W. Moon and Y. G. Kim, "Extending the TAM for a World-Wide-Web context," Inf. Manag., vol. 38, no. 4, pp. 217-230, 2001.

[69] P. A. Dabholkar, "Technology-based service delivery: A classification scheme for developing marketing strategies. In Swartz, T. A., Bowen, D. E., Brown, S. W. (Eds.)," Adv. Serv. Mark. Manag. Greenwich, CT JAI Press, pp. 241-271, 1994.

[70] J. Agarwal, R., and Prasad, "A conceptual and operational definition of personal innovativeness in the domain of information technology," Inf. Syst. Res., vol. 9, pp. 204-215, 1998.

[71] J. Webster and J. J. Martocchio, "Microcomputer playfulness: Development of a measure with workplace implications," MIS Q. Manag. Inf. Syst., vol. 16, no. 2, pp. 201-224, 1992.

[72] A. M. Fiore, J. Kim, and H. H. Lee, "Effect of image interactivity technology on consumer responses toward the online retailer," J. Interact. Mark., vol. 19, no. 3, pp. 38-53, 2005.

[73] J. Kim and S. Forsythe, "Hedonic usage of product virtualization technologies in online apparel shopping," Int. J. Retail Distrib. Manag., vol. 35, no. 6, pp. 502-514, 2007.

[74] J. Kim and S. Forsythe, "Adoption of virtual try-on technology for online apparel shopping," J. Interact. Mark., vol. 22, no. 2, pp. 45-59, 2008. 
[75] J. Kim and S. Forsythe, "Factors affecting adoption of product virtualization technology for online consumer electronics shopping," Int. J. Retail Distrib. Manag., vol. 38, no. 3, pp. 190-204, 2010.

[76] E. Pantano and R. Servidio, "Modeling innovative points of sales through virtual and immersive technologies," J. Retail. Consum. Serv., vol. 19, no. 3, pp. 279-286, 2012.

[77] T. L. Huang and S. Liao, "A model of acceptance of augmented-reality interactive technology: the moderating role of cognitive innovativeness," Electron. Commer. Res., vol. 15, no. 2, pp. 269-295, 2015.

[78] I. Moore, G. C., and Benbasat, "Development of an instrument to measure the perceptions of adopting an information technology innovation.," Inf. Syst. Res., vol. 2, pp. 192-222, 1991.

[79] I. Fishbein, M. and Ajzen, "Understanding attitudes and predicting social behavior. New Jersey: Prentice-Hall.," 1980.

[80] J. Cho, "Likelihood to abort an online transaction: Influences from cognitive evaluations, attitudes, and behavioral variables.," Inf. Manag., vol. 48, pp. 827-838, 2004.

[81] P. A. Adams, D. A., Nelson, R. R., and Todd, "Perceived usefulness, ease of use, and usage of information technology: A replication.," MIS Q., pp. 227-247, 1992.

[82] V. Segars, A. H., and Grover, "Re-examining perceived ease of use and usefulness: A confirmatory factor analysis.," MIS Quarterly, December, pp. 517-525, 1993.

[83] S. Loker, Mass customization and sizing. In S. P. Ashdown (Ed.), Sizing in clothing: Developing effective sizing system for readyto-wear clothing. Cambridge: Woodhead Publishing., 2007.

[84] E. Loker, S., Ashdown, S., \& Carnrite, "Dress in the third dimension: Online interactivity and its new horizons.," Cloth. Text. Res. J., vol. 26, no. 2, pp. 164-174, 2008.

[85] S. Kim, J., \& Forsythe, "Adoption of sensory enabling technology for online apparel shopping.," Eur. J. Mark., vol. 43, no. 9,10, pp. 1101-1120, 2009. 